\title{
Literature Obsolescence, Dispersion, and Collection Development
}

\author{
George V. Hodowanec
}

This study determines annual book obsolescence rates for individual instructional departments within a university. Analysis of such factors as immediacy and intensity of peak usage, use dispersion, and the commonality of use have helped to develop an acquisition priority weighting $(A P W)$ formula. The function of the APW is to serve as a guide in the collection development process. The Circulation Commonality Table, the Dispersion Table, and the Immediacy/ Intensity Table were used to refine the well-known Pareto Principle and Trueswell's 80/20 rule. This study identifies specifically which one-third of total resources receives two-thirds of total use, thus, the $1 / 3-2 / 3$ rule was developed.

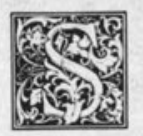

everal factors may contribute to book obsolescence: the usage rate of a book from the high point of its circulation, subsequent natural decline in circulation, and finally its ultimate low point of circulation. Although some of these factors are perhaps too varied and too subjective to enumerate and analyze, especially in academic libraries, it is yet possible to observe certain general, repeated patterns in the circulation rate of books in all subject classifications from the time of acquisition to the time of least circulation. ${ }^{1}$ Likewise, several factors may contribute to book dispersion, ${ }^{2}$ the use of books classified in one subject area by students majoring in another subject area-the use of math books by music majors, for example. Obsolescence and dispersion may be interrelated to some extent. Widely dispersed use may affect obsolescence rates in certain subject classifications. Widely dispersed use soon after acquisition may increase a book's rate of obsolescence because such use raises its peak usage rate. However, widely dispersed use throughout a book's life may tend to stabilize its rate of obsolescence because the instructional department whose curriculum that book supports is not solely responsible for its use. At the other extreme, however, narrowly dispersed and nondispersed library holdings may exhibit slower, more stable rates of obsolescence because no "outside' demand artificially increases a nondispersed volume's peak usage rate. Conversely, high or low obsolescence rates may affect dispersion by encouraging or discouraging widespread early or lifetime use of materials.

Obsolescence and dispersion may both be influenced by the hard or soft (axiomatic or judgmental) nature of subject areas, ${ }^{3}$ by variations in instructional methodology, and by periodic curricular modifications at the college or university of which a given academic library is a part. Since obsolescence and dispersion are reflections of user behavior and since hard or soft subject areas and differences in teaching methods or curricula can be accounted for, study of the statistical data that reflect user behavior and consideration of the types of and rationales for user behaviors thus reflected would enable academic libraries to prepare meaningful, practical collection development guide- 
lines based on local use patterns. Such guidelines would be an accurate response to the needs (as demonstrated by use) of an academic library's primary patrons, the students of the college or university. The goal of collection development guidelines developed from analyses of obsolescence data, dispersion data, and behavioral research will be to provide an academic collection which maintains adequate holdings to support the curriculum of a college or university while avoiding high obsolescence rates and low use rates, but sustaining well-dispersed holdings.

\section{LITERATURE REVIEW}

Obsolescence of materials in libraries has been recognized throughout the history of libraries, but only since World War II has it been more and more frequently studied. In 1947, Gosnell sought to establish mortality formulas for books akin to insurance company analyses of mortality rates among groups of people. Just as insurance companies predict the number of people in given groups who will die after varying periods of time, although no one can predict just which people will die, Gosnell wanted to predict mortality rates for books in libraries. ${ }^{4}$ In 1950, Gosnell advocated "systematic weeding" of library collections, bringing considerations of obsolescence into the realms of effective library management. ${ }^{5}$ In 1967, Hardin reminded librarians that there is no finite limit to the rate of increase of a collection; therefore, microfilming, microcarding, and the like are not really solutions to the problem of rapidly growing collections. Hardin contended, "either we must continually diminish the rate of increase or we must introduce what may be termed a mortality factor and eliminate individuals whose procreation we have permitted."'6 In 1970, Brookes analyzed the "obsolescence of special library periodicals," refining the techniques used to determine obsolescence rates.' In 1973, Brookes presented graphic methods for plotting obsolescence in periodical literature and observed that "at the present time there is no general agreement on how scatter should be defined or measured," although he added, "It seems likely that scatter and obsolescence are related, but that both are determined by rate of growth-the faster the rate of growth, the less the scatter and the more rapid the obsolescence. ${ }^{\prime 8}$ In 1974, Line and Sandison warned that "obsolescence tends to be a loaded term because it does not distinguish decline in use from decline in value or recognize the possibility of increase in use and that current nonuse does not necessarily mean either obsolescence or lack of value. ${ }^{\prime \prime 9}$ In 1975, Hodges noted that the most useful part of a book's existence is in the first three years after publication and that the acquisitions and cataloging procedures take too long a time out of a book's period of greatest demand. ${ }^{10}$ The decade of the 1970 s continued to see the publication of studies addressing obsolescence and collection growth.

An analysis of the entire range of previously published studies reveals, however, that most obsolescence research deals with periodical literature, not with books. Moreover, identifying literature relevant to the relationship of obsolescence and collection development is hampered by the indexing of publications under headings not readily discernable as pertinent to the subject. Therefore, as an aid to future studies of obsolescence and collection development, a suggested reading list of published articles appears in appendix A.

\section{METHODOLOGY}

In order to provide direction for the process of data accumulation for this study, the decision was made to analyze one academic library's annual circulation (William Allen White Library, Emporia State University, 1980 calendar-year circulation), utilizing distinct academic instructional departments as units of comparison. These departments are relatively stable units that enable patterns of library use to be related to curricular programs.

Departmental curriculum-supporting collections were identified through analysis of the content of each course listed in the university's course catalog and subsequent comparison of that content with subject classifications in the Dewey decimal system, by which the university's library materials are classified. Next, any 
conflicts between course titles and descriptions and the appropriate Dewey classifications were resolved.

All calendar-year 1980 records of student circulation were examined, and the catalog numbers of volumes that had been circulated were grouped by Dewey divisional numbers (the second-level classifications summarizing one hundred subject areas) corresponding to instructional departments. Data on books circulated in 1980 were then grouped to show the year of acquisition for each volume circulated, and this information was collated with each instructional department's previously identified curriculum-supporting collection. This process was applied to volumes circulated in 1980 and acquired in any of the preceding twenty-two years. For the purpose of this study, acquisition records were accepted as indicators of a book's first availability to library patrons.

The total number of volumes acquired in each Dewey division during each of the preceding twenty-two years was listed. Then, the 1980 figures on circulation of volumes in each Dewey division were arranged to reflect the year of acquisition for each item acquired within the preceding twenty-two years. Finally, the number of volumes circulated in 1980 from each Dewey division's annual acquisition list was divided by the total number of volumes in each corresponding annual acquisition list. This process for the hypothetical Dewey division $\mathrm{XYZ}$ would be illustrated thus:

Dewey Division Number: XYZ

Total 1980 Circulation: 1,000 volumes

Annual ratios of $\mathrm{XYZ}$ volumes circulated in 1980 (by year of acquisition) to the total XYZ volumes acquired (by same year of acquisition):

$\begin{array}{lllllll}1979 & 1978 & 1977 & 1976 & 1975 & 1974\end{array}$ $100 / 200 \quad 180 / 220 \quad 210 / 215 \quad 150 / 205$ 95/195 90/210

$\begin{array}{llllll}.50 & .72 & .98 & .73 & .49 & .43\end{array}$

By grouping the circulated volumes according to their Dewey divisional classifications and their years of acquisitions, information on book use as a function of time for each library subject area of each instructional department's curriculumsupporting collection was generated. This information was used to plot obsolescence graphs for the individual instructional department collections, for groups of these department collections comprising four broad disciplinary divisions (fine arts and humanities, life science, pure and applied sciences, and social and behavioral sciences), and for the overall library collection.

Circulation graphs were plotted by year of acquisition for every instructional department; these graphs were then grouped according to their unique behaviors of usage, and five representative graphs were selected to show standard and unique obsolescence patterns. The curves from these five graphs were superimposed to illustrate diverse patterns of book use as a function of time. The superimposed curves represented different use patterns observable within library circulation.

The social studies/anthropology (SSA) curve most closely correlated with the library average (LA) curve, with a mathematical coefficient of correlation of .98. Similar use patterns were demonstrated in the curves of the biology, education, English, library science, mathematics, and physical sciences collections. The extent to which these curves paralleled the LA curve varied, but their coefficients of correlation (ranging from .80 for English to .98 for physical science) indicated a high degree of similarity in use patterns. The curve for the business (BUS) collection was considered a relatively close match to the LA curve and the aforementioned curriculum-supporting collection curves, with one exception. The BUS curve displays an extremely high use rate for the first two years after books in this collection are acquired; then the intensity of use drops, and the remaining twenty years of use patterns show close correspondences to the LA curve. Because of the steep rate of use during the first two years of circulation, the BUS curve showed only a .78 coefficient of correlation to the LA curve.

The home economics (HE) collection curve illustrated an erratic use pattern. Its coefficient of correlation (.83) was somewhat lower than the .98 coefficient for the SSA curve, but was within the high range of correlations to the LA curve. The art, 
health and physical education, industrial education, psychology, and speech collections revealed similar erratic use patterns, with coefficients of correlation to the LA curve ranging from .57 for health and physical education to .97 for industrial education. All the curriculum-supporting collections in this group exhibit multiple circulations of books during the first two years following acquisition.

The foreign languages (FL) collection revealed a unique use pattern. Its rate of circulation of books remained consistently below the LA rate, but in all other respects it closely paralleled the LA curve. Its .85 coefficient of correlation indicated a high correspondence to the LA curve. The use pattern of the fiction collection, studied separately, exhibited highly erratic use.

Repeated attempts were made to manipulate the plotted data into mathematical, computer-generated expressions describing book use as a function of time; however, all attempts (except linear representations of obsolescence rates) to generate mathematical expressions of book use as a function of time were unsuccessful. Therefore, the data reflecting book use over time were analyzed as representations of user behavior patterns. Conclusions reached by such analyses were discussed with the librarians responsible for collection development as well as with faculty who are professionally responsible for directing student use of library holdings. These people's expertise was called upon to refine or refute preliminary conclusions.

All comments were considered valid, and an academic collection use analysis was included in this study so that the use of academic collections by declared majors specializing in an area could be compared to university-wide use of these same academic collections. With such analysis and comparison, those responsible for making collection development decisions could avoid slighting collections showing heavy use by declared majors in a given subject area.

Although past, present, and potential user behavior patterns were discussed with those professionally involved with the university and the academic library being studied, across the board, no one was able to offer new insights into the obsolescence pattern of books or into the factors that might affect the obsolescence sequence. The most immediately comprehensible graphic depiction of obsolescence seemed to be linear plotting of usage rate as a function of time, so linear representations of the book obsolescence sequence were determined for the overall library, the four broad disciplinary divisions, and the individual instructional departments (art, business, and mathematics, for example). Higher correlation coefficients between divisional and departmental obsolescence curves and the overall library obsolescence curve were found to exist with linear regression plotting than with exponential decay plotting. (See figure 1, column F.) Since no useful conclusions could be drawn from the "plateau" years, the years of steady low circulation of a book after it reaches its lowest point of circulation, and since these "plateau" years' circulation data lowered the coefficient of correlation of divisional and departmental curves with the overall library curve, preferability was given to the linear representations and to conclusions that could be drawn from them.

While circulation is admittedly not an exact measure of book use, for the vast majority of library holdings, circulation is an adequate barometer of use, thus circulation data were accepted as indicators of use in all cases. Book use could be measured by citations of library holdings in research works done at an academic library, but such a measurement of use would be equally as incomplete as circulation records. Reshelving records could be kept and used to measure book use, but such records would not include books inadvertently removed from open stacks or books reshelved by patrons who ignored requests not to reshelve materials. It seems much more acceptable, then, to relate use to circulation, acknowledging the flaws in such a relationship, but achieving a measure of the actual possession of a library holding by a library patron for whatever reason.

\section{ANALYSIS OF OBSOLESCENCE FINDINGS}

Decreased use over time is a normal, 
predictable, well-known characteristic of library holdings. However, knowing that obsolescence is characteristic of library materials is of little use; knowing the specific rate of decreased book use, or book obsolescence, within well-defined subject groups would be more valuable because acquisitions requests and decisions are made in regard to such groupings. Column A of figure 1, the Obsolescence Analysis Matrix, reveals the annual obsolescence rate for four major disciplinary division collections (fine arts and humanities; life science; pure and applied sciences; and social and behavioral sciences), for sixteen individual academic department collections comprising the four disciplinary categories, and for the entire library.

In the process of calculating the individual department collection obsolescence rates, books circulated in 1980 were grouped by the year of publication (acquisition) and by Dewey second summary divisional subject areas that directly correlated to the content of courses offered in each instructional department. With each of these departments previously defined as a unit made of specific informational subject areas (based on the collation of the course descriptions and the subject classification headings in the second summary divisions of the Dewey list), a relatively stable subject-area profile of curriculumsupporting collections was revealed for each department.

The annual obsolescence rate for all academic department collections displayed a range of 6.23 percent, with a low of 2.27 percent in the foreign languages collection and a high of 8.50 percent in the business collection. The department collections varied within one standard deviation for almost two-thirds of these collections.

The obsolescence rate of each individual instructional department collection indicates the rate at which books become less frequently used and, therefore, have less informational value to library patrons. The obsolescence rates of the foreign languages collection (2.27 percent per year) and business collection ( 8.50 percent per year) indicate that books in the former collection do not need to be replaced as quickly as books in the latter because books supporting the curriculum of the foreign languages department obsolesce at roughly one-quarter of the rate of books supporting the curriculum of the business department. Although such a generalization seems supportable by reference to obsolescence rate patterns, most generalizations based solely on the ranking of obsolescence rates are insufficiently representative of user behaviors to determine collection guidelines.

Closer consideration of obsolescence rankings suggested that variations in the obsolescence rates of individual academic departments might result from several influences. For example, substantial growth and expansion of theory, research, and publication in a particular instructional field (e.g. business) seem to result in a higher annual rate of book obsolescence for that field's curriculum-supporting collection. Also, an instructional field that relies heavily on visual examples or descriptions of processes (art and architecture, for instance) to generate fresh approaches to its subject matter will tend to make its acquisitions obsolesce at a higher annual rate because users seem to obtain and review the volumes as soon as the books become available in the library, causing early multiple circulation patterns, then circulate these volumes later at more-standard rates. Moreover, academic fields which are in a developmental or redevelopmental state, undergoing refinements in the methodology and technology of their informational domain (e.g., industrial education, home economics, and computer science) tend, likewise, to demonstrate higher than average rates of obsolescence in their collections. Conversely, academic fields that rely upon revised versions or new editions of already existing materials (e.g., English) tend to amass collections with below average annual obsolescence rates. Finally, certain instructional fields and certain curriculum offerings are primarily textbook oriented. When these fields and courses do not exhibit rapid expansion of theory, research, and publication, their curriculum-supporting collections tend to have below average annual use and obsolescence.

There are other factors closely related to obsolescence that may be fruitfully con- 


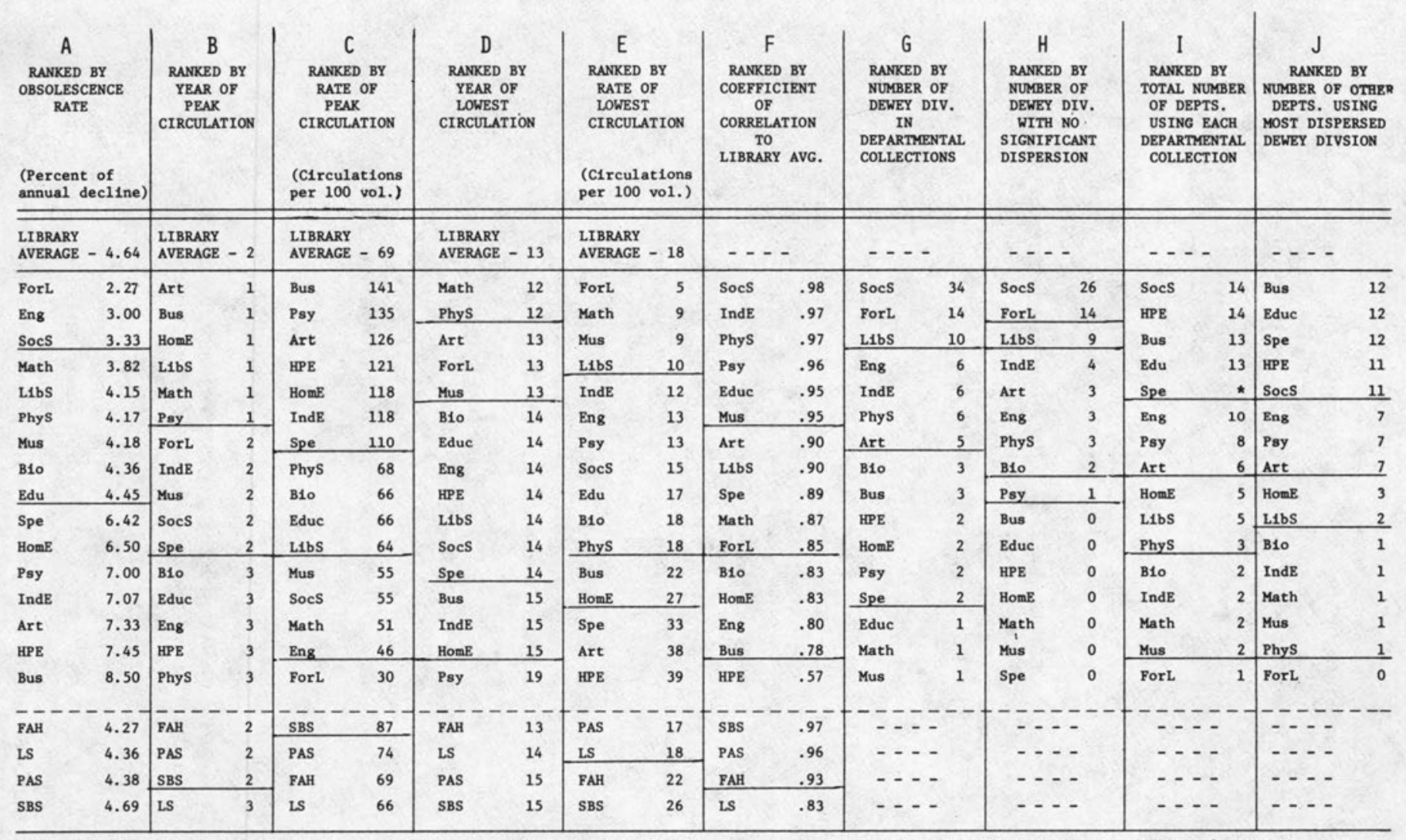

KEY: Art--Art; B1o--B1ology; Bus--Business; Educ--Education; Eng--English; FAH--Fine Arts \& Humanities; ForL--Fore1gn Languages; HomE--Home Economics; HPE--Health \& Physical Education; IndE--Industrial Educat1on; L1bS--Library

*Core 000 's in Libs, Science; LS--L1fe Science; Math--Mathemat1cs; Mus--Mus1c; PAS--Pure \& Applied Sc1ences; PhyS--Physical Science;

Core 790 's in $\mathrm{HPE}$ Psy--Psychology; SBS--Social \& Behavioral Sciences; SocS--Soc1al Studies/Anthropology; Spe--Speech

FIGURE 1

Obsolescence Analysis Matrix 
sidered in conjunction with this analysis of obsolescence rates. Two of the most significant of such factors are the period of peak use and the corresponding magnitude of peak use. The period of peak use reveals the "immediacy" of user need, and the magnitude of peak use reveals the "intensity" of user need. Rankings of immediacy and intensity appear in columns $B$ and $C$ of figure 1 .

The immediacy factor indicates the urgency with which books are needed by library patrons. Six academic instructional departments (shown in column B) exhibit peak circulation of their library materials one year after books in their curriculumsupporting collections have become available in the library. Four of these same departments (shown in column C) also appear in the top-intensity group, exhibiting the highest ratios of circulation transactions per one hundred books acquired. These reflections of immediate and intense use by four academic departments support decisions to acquire materials for their collections as quickly as possible. These departments, and only these departments, demonstrate patron behaviors which recommend such quick acquisition of new publications.

Instructional departments whose peak use of their curriculum-supporting collection occurs in the second or third year after acquisition do not exhibit sufficient immediacy to necessitate urgent purchasing of their requests. Book purchases for these departments should be executed deliberately and carefully so that resources are not wasted and so that curricular programs do not suffer. Most instructional department collections with delayed peak use periods also exhibit an intensity of use that is lower than collections with immediate peak use periods. For example, column B of figure 1 shows that materials in the music department collection reach their peak usage period two years after acquisition, and column $C$ shows that these materials' intensity of use during this period is only 55 circulations per hundred books acquired.

Books in subject areas that reach peak immediacy after two or three years offer excellent possibilities for resource-sharing efforts among libraries. Items in categories with a moderate or low use intensity and a later immediacy factor give' a library plenty of time to determine whether independent acquisition or shared access is an appropriate response. Interlibrary loan records of items in low use and late immediacy categories will pinpoint the occasional heavily used item, and the library can acquire it. Other items in these categories are perhaps best borrowed from libraries at institutions where the curricular programs they support are especially emphasized.

Data in columns D and $\mathrm{E}$ represent the years that books within the various curriculum-supporting collections reach their lowest use and the rate of use in each curriculum-supporting collection during those years. The range of lowest rate of use varies from 5 to 39 hundred volumes and occurs twelve to seventeen years after books are acquired by the library.

Although some studies have speculated that a certain low point in use justifies weeding via secondary storage or discarding, no sound decisions about weeding can be made unless each library considers the period of lowest use along with its own financial and physical resources, including operating funds, availability and accessibility of primary and secondary storage space, and storage costs in primary and secondary storage locations. Each library should determine for itself the cost-effectiveness of storing and maintaining given volumes if their chances of circulating in a given year are only one in twenty. At some point, borrowing infrequently requested volumes through interlibrary loan will be more cost-effective for medium-sized libraries with limited budgets and space than holding those volumes will be. However, this point will vary for each library. Decisions about discarding, putting into secondary storage, or continuing to shelve certain volumes at the primary library facility can be supported in part by the data in columns D and $\mathrm{E}$.

Differing circulation rates at the lowest points of use in each curriculum-supporting collection suggest a variety of conclusions. Although the data appear contra- 
dictory, curriculum-supporting collections with higher annual rates of obsolescence also tend to be collections with higher rates of use at their lowest points of use. Conversely, the collections with lower annual rates of obsolescence tend to show lower rates of use at their lowest points. For example, the business, health and physical education, art, industrial education, home economics, and speech collections all display high rates of obsolescence and relatively high rates of circulation fourteen to seventeen years after acquisition of books, for those collections. However, the foreign languages and mathematics collections show low rates of obsolescence and relatively low rates of circulation twelve to thirteen years after volumes have been acquired. Therefore, one must not assume that high rates of obsolescence indicate collection holdings that may become very little used, nor can one assume that low rates of obsolescence indicate stable, high use.

Six of the nine departmental collections in the lower half of column D, collections with relatively high circulation rates at the end of their obsolescence sequence, are also in the upper half of column I, which ranks the range of dispersion of each curriculum-supporting collection. Widely dispersed use of a curriculum-supporting collection apparently tends to elevate that collection's circulation rate at the lowest point of its obsolescence sequence.

Column F shows how well the individual collections' graphs of circulation patterns throughout the obsolescence sequence matched the corresponding graph for overall library circulation. Circulation plotted as a function of time for each academic instructional department's curriculum-supporting collection demonstrated many variations among departmental collections. Measured against overall library circulation and in terms of the coefficient of correlation, however, departmental collections generally correlate highly. The social studies/anthropology collection reveals a .98 coefficient of correlation to the overall library graph of circulation during the obsolescence sequence. In this study, therefore, the graphic patterns of the social studies/anthropology department curve can be used to represent the use patterns of overall library circulation.

Columns G, H, I, and J present interrelated data on the factor of dispersion. These columns reflect data showing book use as a function of the magnitude and range of the circulation of an academic department's curriculum-supporting collection by patrons not majoring in that department's curricular programs. Dispersion appears to be a very important factor to consider in the priority ranking of books that have been requested for acquisition. Column $\mathrm{G}$ identifies the number of Dewey divisions that directly relate to the subject content of the courses offered by a given academic department. These Dewey divisions form the fundamental curriculum-supporting collection for a particular department, that is, the collection of books in subject areas most closely related to the unique curricular program of that particular department. The social studies/anthropology collection has the largest number of Dewey divisions that directly relate to subject areas within its curricular programs, while the music department has the smallest number of such Dewey divisions.

While some variations of the boundaries of a particular academic department's curricular domain are likely, the overall subject profile of that particular department is likely to remain reasonably stable. Hence, column $\mathrm{H}$ identifies the number of Dewey divisions considered unique to a particular department which are not significantly circulated by users associated with other instructional departments. For instance, it was found that twenty-six Dewey divisions are, for the most part, relied upon only by patrons associated with the social studies/anthropology department. However, there are eight Dewey divisions (compare column $\mathrm{H}$ and $\mathrm{G}$ ) that support the social studies/anthropology curriculum but are utilized by students not associated with the social studies/anthropology department. At the other end of the scale, no Dewey divisions in the business department's collection are used exclusively by business majors.

Columns $\mathrm{H}$ and $\mathrm{G}$ also show the extent 
to which individual academic-department collections with many Dewey subject divisions may maintain curricular individuality. Relatively exclusive use of the resources in those Dewey divisions associated with a particular instructional department shows the extent to which certain collection development requests will need to be considered simply on the basis of departmental curriculum support. No significant dispersion of a given number of Dewey divisions in a departmental curriculum-supporting collection suggests the need for curricular guidelines as part of the collection development review process. The larger the number of Dewey divisions unshared by other instructional departments, the more that acquisitions decisions must be based upon the requirements of curricular programs within the particular instructional department.

Column I identifies the total number of instructional departments using each individual instructional department's curriculum-supporting collection. For instance, a total of fourteen teaching departments use Dewey divisions that are defined as unique subject areas relating to the curricular programs of the social studies/anthropology department. One analysis of this factor shows that books in the curriculum-supporting collections of certain academic departments are used not only to support the informational needs of that department's own students but also of other students not associated with that particular department. Thus, while the collection development selection process should give priority consideration to books that are needed to support the curricular programs of a particular instructional department, the argument favoring the acquisition of a given book is strengthened whenever it is used by patrons associated with other departments.

Column J identifies the dispersion range of the single Dewey division in each academic department collection with the highest range of dispersion. For instance, one category in the business department collection is also used by students associated with twelve other academic departments. While there are a number of individual Dewey divisions that are used by students associated with departments other than the department drawing curricular support from these subject classifications, the dispersion thus reflected may be concentrated in only a few instructional departments. The figures in column J, however, provide information that will assist in assigning relative importance to acquisitions requests on the basis of general use. The opposite argument can then be made that if there are none or very few dispersed Dewey divisions related to a given academic department, acquisitions decisions concerning its curriculumsupporting collections will be almost exclusively based on the importance of the library's support of that department's curricular program.

To determine university-wide book-use relationships and departmental needs for library support of curricular programs in which students may take an academic degree, circulation and collection-size data were further analyzed. Figure 2, Academic Collection Use Analysis, presents the findings of this usage investigation. The number of volumes in each individual academic department's curriculumsupporting collection, already identified as the group of pertinent Dewey divisional classifications, was compared to the library's total holdings in curriculumsupporting collections so that the size of each departmental collection could be ranked as a percentage of the total size of all departmental collections. Likewise, a twelve-month total of circulations for each academic department's collection was compared to the library's total twelvemonth circulation of volumes from curriculum-supporting collections in order to rank circulations from each individual academic department's collection as percentages of the library's total circulations of curriculum-supporting volumes. The ratio of an academic department's percentage of total curriculum-supporting circulations to its percentage of total curriculum-supporting holdings provided a coefficient of usage, a mathematical quotient reflecting the relative universitywide patron demand for books from each academic department's collection.

In a similar manner, the twelve-month 


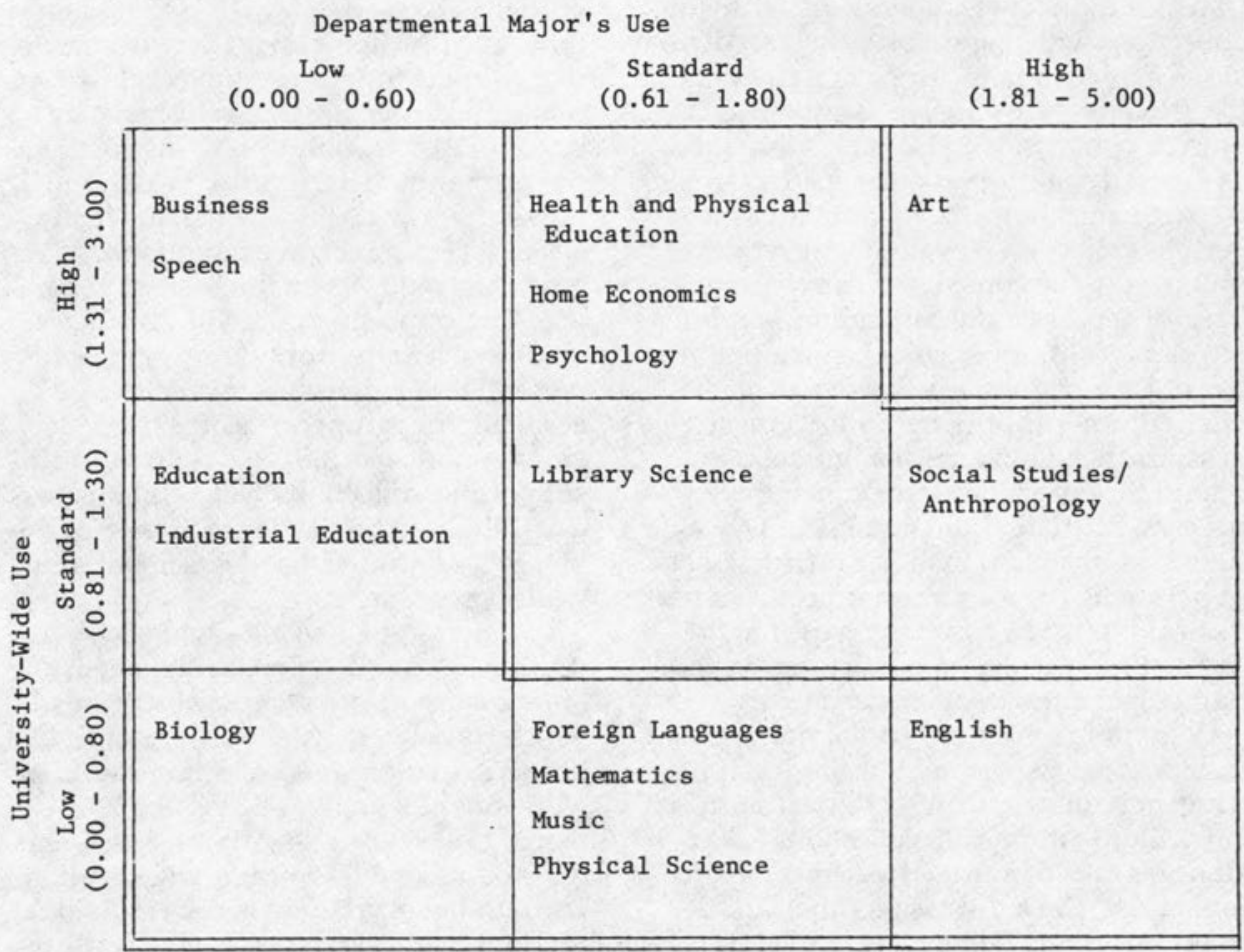

Key For Collection Use Analysis

Departmental Collection
Art
Biology
Business
Education
English
Foreign languages
Health and physical education
Home economics
Industrial education
Library science
Mathematics
Music
Physical science
Psychology
Social studies/anthropology
Speech

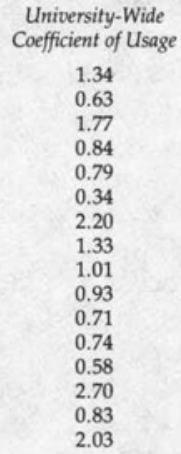

Departmental Majors' Coefficient of Usage

FIGURE 2

Academic Collection Use Analysis

totals of declared majors in each academic department were compared to the university's twelve-month total of declared majors in order to rank the number of declared majors in each department as a percentage of the year's total number of declared majors. The ratio of each academic department's percentage of total curriculum-supporting circulations to its percentage of total declared majors provided a coefficient of departmental majors' usage.

By grouping departmental collections according to their low, standard, or high university-wide use and their low, standard, or high declared majors' use, the 
cross-comparison format of figure 2 was generated. Departmental collections appearing midway on the university-wide axis reflect soundly developed collections for which the relative use rates match the relative collection sizes; current acquisitions and weeding policies should probably be continued in future collection development. Departmental collections appearing at the bottom of the universitywide use axis reflect overdeveloped collections for which the relative use rates are less than the relative collection sizes; acquisitions should probably be more carefully screened and judicious weeding of unused volumes should be applied in future collection development. Departmental collections appearing at the top of the university-wide use axis reflect underdeveloped collections for which relative use rates are greater than relative collection sizes; judicious broadening of acquisitions policies might be considered for future collection development.

On the departmental majors' use axis, collections appearing midway reflect standard use by declared majors in the departments listed. Collections appearing at the left end of the departmental majors' use axis indicate light use by declared majors; the curriculum and/or the teaching methods for the departments listed are not "library-intensive." Collections appearing at the right end of the departmental majors' use axis indicate heavy use by declared majors; the curriculum and/or teaching methods for the departments listed are "library-intensive."

Review of an academic collection use analysis table based on circulation and declared-major data for any given academic library should indicate, to those responsible for collection development, the relative importance of the library's support of various departmental curricular programs in addition to the relative importance of the library's support of academic collections showing varying degrees of dispersed use. The use-support relationships are dynamic, changing as university emphases change. Academic librarians must keep both campus-wide needs and degree-program needs in mind as collection development decisions are made. It is important to note, however, that figure 2 was compiled from 1982 circulation data. Yet its results reinforce the use findings from the 1980 circulation data presented in figure 1 . Thus, replication of the study at a different time and for different purposes tended to support finds of low, standard, and high usage of groups of library holdings affiliated with academic departments.

\section{CONCLUSIONS AND RECOMMENDATIONS}

Initial evaluation of all the abovementioned data made it tempting to offer a variety of general policy directives. However, it is not the purpose of this study to determine the minimum size of core collections or to specify the number of titles that should be acquired in any specific subject area. In both instances, such determinations require subjective judgments from librarians, taking into account the existing size of the resources in a particular subject area, the level and depth of an instructional program, and the overall goals of a university. However, consideration of the number of titles to be purchased in a particular subject area should be based not only on use-related factors but also on the number of titles being published in that subject area.

First, a study of circulation patterns suggests that "basic" or "core" or "essential" collections should be developed after review of a number of integrally related use factors rather than developed around arbitrarily specified numbers of volumes per student. Analysis of the use patterns in curriculum-supporting collections avoids the subjectivity with which titles are recommended in standard library guides for collection development. Standard catalogs and lists of "'best books, " although published regularly and used widely, cannot reflect individual academic libraries' local use patterns and corresponding patron needs as effectively as a faculty member's preference or a librarian's knowledge of actual patron use and of strengths and weaknesses in a particular collection.

Circulation data also seemed to indicate 
that certain books were being acquired in certain subject areas of the Dewey divisions in preparation for later academic use. Certain collections in the low-tomiddle range of immediacy and intensity of use continued to show regular growth in acquisitions. This behavior seemed to indicate that some books in these collections were acquired on the basis of perceived potential use, not on the basis of actual curriculum-supporting use.

This study was structured from the outset to specify curriculum-supporting collections that reflect closed subject areas of various academic departments' specializations. Use data, though, indicated significant dispersion of volumes found in several so-called closed academic collections. In other words, use data seemed to reflect the interdisciplinary dispositions of academic library patrons. Initially, dispersion appeared to be a balancing factor that prevented rapid rates of obsolescence in collections with wide circulation among patrons who did not show declared majors in the departmental curricula that these collections support. It seems, however, that if usage is widely dispersed early in the library life of certain components of a collection, then the early part of that collection's obsolescence sequence will vary greatly from the overall library pattern. If, on the other hand, usage is well dispersed throughout the entire library life of certain components of a collection, then that collection's obsolescence sequence will tend to correspond to the overall library pattern. Continued review of the particular dispersed components of a collection is necessary to verify this observation.

Data from figure 1, the Obsolescence Analysis Matrix, were evaluated to determine whether or not they revealed any information valuable to the forming of collection development guidelines. Column B, "Year of Peak Circulation," showed the immediacy with which books in each academic collection circulated. Column C, "Rate of Peak Circulation," showed, in terms of circulations per one hundred volumes, the intensity of circulations in each academic collection during the years identified in column B. Since the probable im- mediacy of need and the probable intensity of use are important to the making of collection development decisions, these data were combined in figure 3 , the Immediacy/Intensity Table. Combined, the data reveal three distinct groups or communities of use: first, high intensity (110-150 circulations per hundred, multiple circulations of volumes) and first-year immediacy; next, moderate to high intensity and first to second-year immediacy; finally, low to moderate intensity and first to third-year immediacy. Books in the departmental collections making up the high-intensity and first-year-immediacy group show the earliest and heaviest use; therefore, priority should be assigned to their acquisitions when faculty or librarians request them. Books in the other two groups show less immediate need; therefore, other factors would be necessary to encourage early acquisitions of new books in the subject areas comprising these departmental collections.

The dispersion data from columns $\mathrm{G}, \mathrm{H}$, $\mathrm{I}$, and $\mathrm{J}$ of figure 1 were arranged to reflect the actual range of dispersion and rate of circulation of the dispersed Dewey divisions within each academic curriculumsupporting collection. Dewey divisions not assigned to curriculum-supporting collections were eliminated from this group so that a view of multidepartmental circulation of Dewey divisions with curriculum-supporting use could be framed. Such a view represents the academic institution's direct influence on book use. First, only those Dewey divisions outside a given instructional department's assigned collection but circulated by that department's majors were listed. Next, the total circulation by declared majors of books from collections outside each instructional department's curriculumsupporting collection was tabulated for each department. Finally, "significant" dispersion was accepted to begin whenever an "outside-major" circulation rate of more than 1.90 percent of the total circulation by each department's declared majors occurred. The entire year's circulation figures for books in the Dewey divisions showing such significant dispersion of use could then be compared to the year's total 
circulation of books to determine the percent of total library circulation for which each range of narrowly to widely dispersed subject divisions accounted. This comparison is reflected in figure 4 , the Dispersion Table. Circulation of books in thirty-two of the one hundred Dewey divisional classifications showed both curricular support and significant dispersion. Books in Dewey divisions with significantly dispersed use by majors in one or more departments outside the department whose curriculum these Dewey divisions support accounted for slightly more than 66 percent of the total library circulation. In other words, two-thirds of total library use was found to stem from circulation of books in one-third of the possible Dewey divisional classifications.

To be certain that the circulation data, on which collection development recommendations would be made, reflected user preferences not solely dictated by curriculum-support requirements, a final tabulation was made of the year's total circulation grouped by patrons' declared major departments but without regard to the curricula of those departments. As presented in figure 5, the Circulation Commonality Table, this tabulation reflects any circulation of books by declared majors from all the departments making up one of the four broad academic disciplinary divisions of the university: fine arts and humanities; life sciences; pure and applied sciences; and social and behavioral sciences. The tabulation was arranged to show which Dewey divisions recorded any circulation of books by majors from all departments in four, three, two, or one of the broad academic disciplines. As the Dispersion Table reflects a curriculum-generated core collection that accounts for 66 percent of book use, so the Circulation Commonality Table shows a user-generated core collection. This userinterest core collection accounted for twenty of the possible one hundred Dewey divisions and 53.5 percent of the year's total library circulation. Of the thirty-two dispersed curriculum-supporting Dewey divisions appearing in the Dispersion Table, eighteen also appear in the top twenty Dewey divisions reflecting user interests in the Circulation Commonality Table. The remaining fourteen dispersed Dewey divisions accounted for 15.5 percent of the year's total library circulation. The user-generated collection and the curriculum-supporting collection together accounted for 69 percent of the year's total library circulation and thirtyfour of the one hundred Dewey divisional subject classifications. The well-known Pareto Principle, echoed in Trueswell's descriptions of the use of a library's total collection, seems to be refined by this breakdown. Rather than 20 percent of the library's holdings satisfying 80 percent of user demand, roughly one-third of the library's subject classifications satisfied two-thirds of user demand. Additionally, the use of precisely identified subject classifications as the basic units of comparison in this study enables one to determine which one-third of the library holdings account for two-thirds of user demand. Within these collections is the basis for sound use-based collection development decisions.

Reference to any of the bibliographic utility data bases or to a CIP can yield the identity of a book's Dewey decimal divisional classification (or the corresponding Library of Congress classification). To begin the process of formulating collection development decisions, the subject-area classification for each requested book should first be identified by the Dewey divisional classification. Then, reference should be made to the Immediacy/Intensity Table (figure 3 ) in order to determine the relative priority ranking of the requested books in terms of time and use. Next, the Dispersion Table (figure 4) and the Circulation Commonality Table (figure 5) should be referred to in order to determine the relative priority ranking of the requested books in terms of curriculargenerated and user-generated dispersed use. Combined, all this information can be put into a simple Acquisition Priority Weighting (APW) formula to aid in the collection development process. The basic form of the APW is APW $=[\mathrm{I}+\mathrm{I}]+[+\mathrm{D}]$ $+[\mathrm{C}]$; it is a sum of ranking values assigned to the position of a book's curriculum-supporting collection and 
Range of Highest Circulation Rate per One Hundred Volumes Acquired:

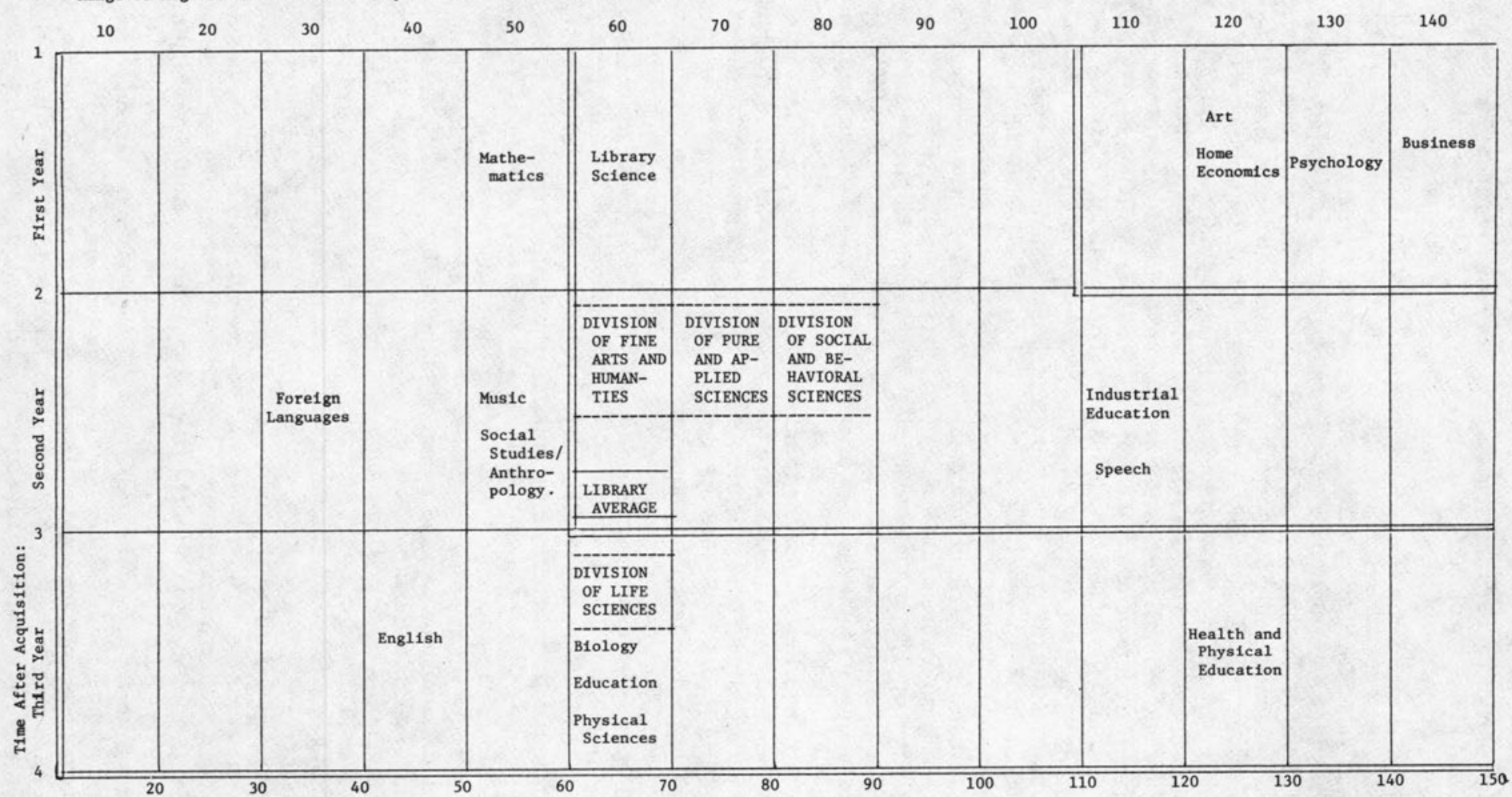

?

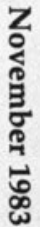


Dewey divisional classification on the Immediacy/Intensity, Dispersion, and Circulation Commonality tables.

The horizontal columns of the Immediacy/Intensity Table refer to the year in which peak usage occurred in a given academic collection. The vertical columns identify circulations per hundred books within the same academic collections. All Dewey divisional classifications in each academic department's collections are uniformly assigned a priority value based on the whole collection's immediacy and intensity ranking. First-, second-, and third-year peak usage are given rankings of 3,2, or 1 respectively. Circulations per hundred are given rankings from 0 to 1 to reflect their circulation ratios; collections with peak circulations per hundred of 40 , 60 , and 110 , for example, are given rankings of $0.4,0.6$, and 1.1 respectively. The sum of each department's year-of-peakusage ranking and its rate-of-peak-usage ranking will comprise the Immediacy/Intensity $[\mathrm{I}+\mathrm{I}]$ factor in acquisitions prioritization. For example, second year peak usage at 50 circulations per hundred would be prioritized thus: $2+0.5=2.5$.

The next component of the APW formula is the Dispersion [1 + D] factor. Books in subject-area classifications with no dispersed use, in other words, with only major-department use, are assigned a dispersion factor of 1 to reflect onedepartment use. Books in subject-area classifications showing use by two or more departments are given priority ranking values by adding the majordepartment dispersion factor (1) to the product of values assigned to the "Percent of Total Library Circulation" and "Range of Departments Using Dispersed Dewey Divisional Classifications" categories. A value of 1 is assigned to the "High Circulation" category; $0.75,0.50$, and 0.25 respectively are assigned to the "Moderate to High," "Low to Moderate," and "Low" circulation categories, the horizontal columns of the Dispersion Table. The vertical columns of this table, reflecting ranges of dispersion, are given values of 1, 2, 3, and 4 for "Low," "Low to Moderate," "Moderate to High," and "High" dispersion respectively. Thus, a book 
RANGE OF DEPARTMENTS USING DISPERSED DEWEY DIVISIONAL CLASSIFICATIONS:

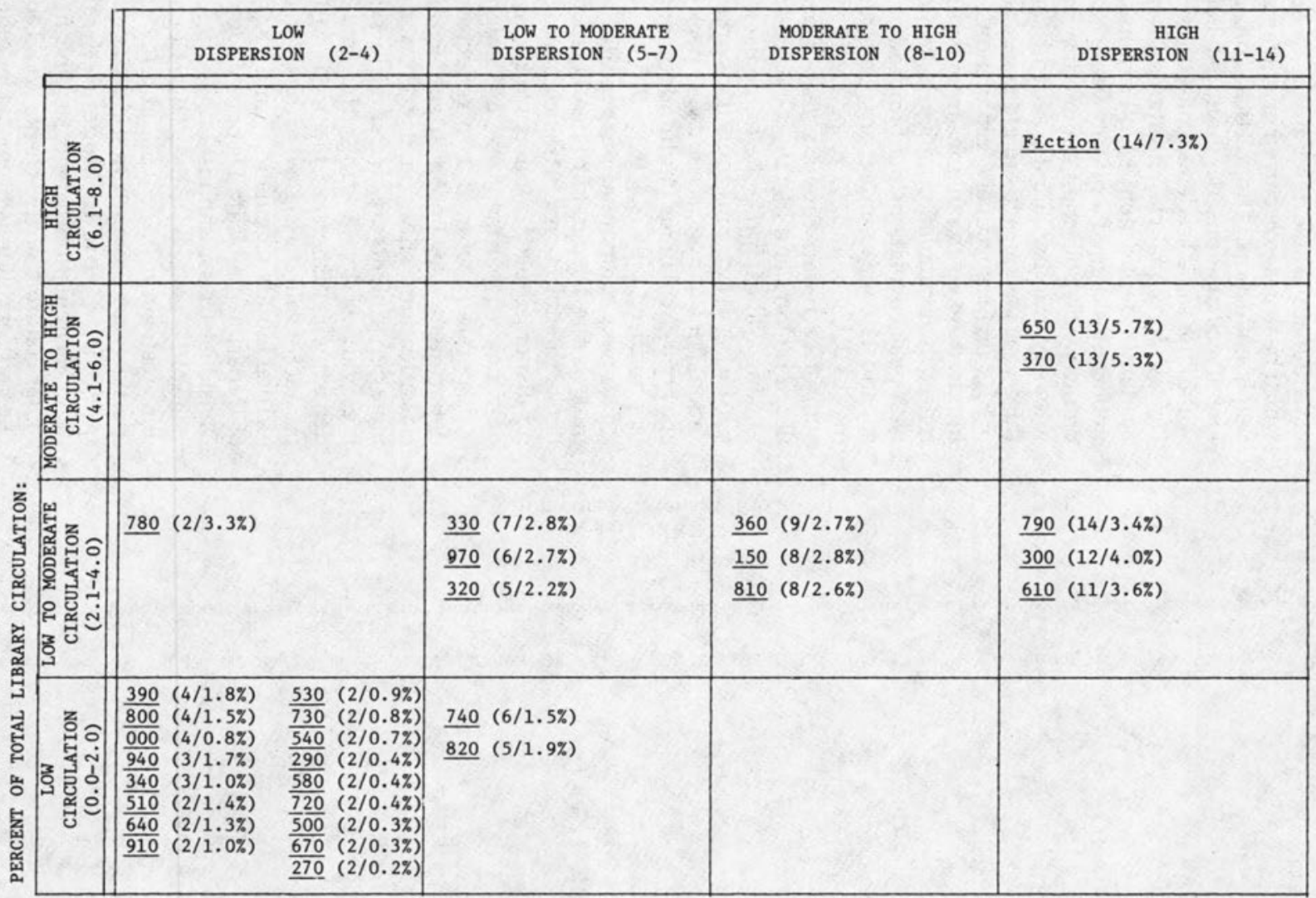

(Note: Dewey divisions with at least two department dispersion--major department and one other-account for more than $66 \%$ of total library circulation. Dewey divisions with only major department use account for less than $34 \%$ of total library circulation.) 


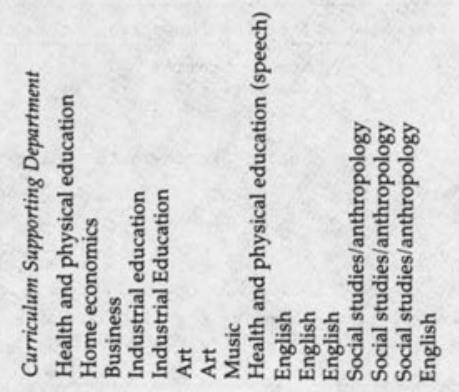

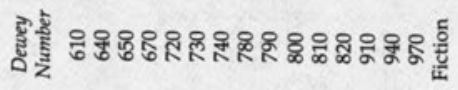

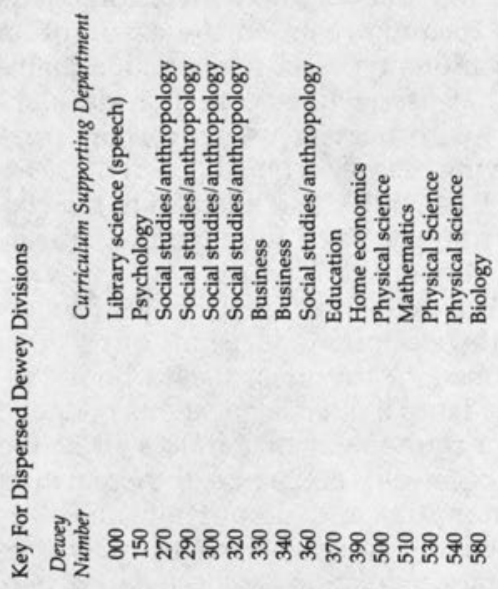

from a subject classification in "Low to Moderate Circulation" and "Moderate to High Dispersion" would be prioritized 1 $+(.75 \times 3)=3.25$.

The third component of the APW formula is the Circulation Commonality [C] factor. Dewey divisional classifications appearing in the categories of one, two, three, or four broad-academic-discipline circulation receive priority values of 1,2 , 3 , and 4 respectively. Books classified in the 720, a Dewey division appearing in the two-academic-discipline circulation group on the Circulation Commonality Table, would receive a priority ranking factor of 2.

The formula, then, for each requested book's APW (acquisition priority weight) is as follows:
$\mathrm{APW}=[$ Value of Peak Usage Year + Peak Number of Books Circulated per 100 Acquired/100]
$+[1+($ Value of Library Circulation Rank $\times$ Value of Dispersion Range Rank)]
+ [Value of Circulation Commonality Rank]

Thus, books appearing in the Dewey divisional subject classification 650 would be prioritized in the following manner:

$$
\begin{aligned}
\mathrm{APW}_{650} & =[3+140 / 100]+[1+(.75 \times 4)]+[4] \\
& =4.14+4+4 \\
& =12.14
\end{aligned}
$$

To determine the usefulness or applicability of the APW formula at libraries other than the William Allen White Library of Emporia State University, a Spearman Rank Order Correlation (rho) test was conducted to compare the use patterns of the Emporia State University, Bucknell University, Colorado State University, and University of Pittsburgh libraries. In collection sizes, these university libraries range from 400,000 to 600,000 volumes (Emporia State and Bucknell) to over $1,000,000$ volumes (Colorado State) to over 2,000,000 volumes (Pittsburgh). According to the Spearman Rank Order Correlation test, the use-pattern correlation between the Emporia State library and each of the other libraries is significant. (See appendix B for each individual corre- 


\begin{tabular}{|c|c|c|c|}
\hline \multicolumn{2}{|c|}{$\begin{array}{c}\text { Dewey Divisions Showing Any Circulation } \\
\text { By Majors From A11 Departments In A11 Four } \\
\text { Academ1c Disciplines }\end{array}$} & \multicolumn{2}{|c|}{$\begin{array}{l}\text { Dewey Divisions Showing Any Circulation } \\
\text { By Majors From A11 Departments In Three } \\
\text { Academic D1sciplines }\end{array}$} \\
\hline Dewey Division & Curr1culum Supporting Collection & Dewey Division & Curriculum Supporting Collection \\
\hline $\begin{array}{l}150 \\
300 \\
330 \\
360 \\
370 \\
610 \\
650 \\
790 \\
\text { Fiction }\end{array}$ & $\begin{array}{l}\text { Psychology } \\
\text { Social Studies/Anthropology } \\
\text { Business } \\
\text { Soc1a1 Studies/Anthropology } \\
\text { Education } \\
\text { Health and Physical Education } \\
\text { Business } \\
\text { Health and Physical Education } \\
\text { (Speech) } \\
\text { Eng11sh }\end{array}$ & $\begin{array}{l}390 \\
620 \\
640 \\
810 \\
970\end{array}$ & $\begin{array}{l}\text { Home Economics } \\
\text { [No Curr1cular Program] } \\
\text { Home Econom1cs } \\
\text { English } \\
\text { Soc1al Studies/Anthropology }\end{array}$ \\
\hline \multicolumn{2}{|c|}{$\begin{array}{c}\text { Dewey Divisions Showing Any C1rculation } \\
\text { By Majors From All Departments In Two } \\
\text { Academ1c Disc1plines }\end{array}$} & \multicolumn{2}{|c|}{$\begin{array}{c}\text { Dewey Divisions Showing Any Circulation } \\
\text { By Majors From Al1 Departments In One } \\
\text { Academic Disc1pline }\end{array}$} \\
\hline Dewey Division & Curriculum Supporting Collection & Dewey Division & Curriculum Support1ng Collection \\
\hline $\begin{array}{l}290 \\
630 \\
720 \\
740 \\
820 \\
910\end{array}$ & $\begin{array}{l}\text { Socal Studies/Anthrolopogy } \\
\text { [No Curricular Program] } \\
\text { Industrial Education } \\
\text { Art } \\
\text { English } \\
\text { Social Studies/Anthropology }\end{array}$ & $\begin{array}{l}130 \\
380 \\
500 \\
510 \\
530 \\
540 \\
570 \\
580 \\
590 \\
660 \\
690 \\
750 \\
780 \\
800 \\
940 \\
\text { Fed Gov't Doc }\end{array}$ & $\begin{array}{l}\text { Psychology } \\
\text { Soc1al Studies/Anthropology } \\
\text { Physical Sc1ence } \\
\text { Mathematics } \\
\text { Physc1al Sc1ence } \\
\text { Physical Sc1ence } \\
\text { B1ology } \\
\text { B1ology } \\
\text { B1ology } \\
\text { [No Curricular Program] } \\
\text { Industrial Education } \\
\text { Art } \\
\text { Music } \\
\text { English } \\
\text { Soc1al Studies/Anthropology } \\
\text { [No Curricular Program] }\end{array}$ \\
\hline
\end{tabular}

FIGURE 5

Circulation Commonality Table

lation value.) This significant correlation supports the hypothesis that use patterns are generally applicable. Emporia State University's APW values for the one hundred Dewey divisions should be broadly consistent with other universities' APW values for similar subject classifications. (See appendix C for Dewey to LC conversion of subject classifications pertaining to academic departments.) Curricular differences may slightly alter individual APW values, but within the high, middle, and low groups of APW values, the same subject classifications should appear, according to the Spearman correlations. (See appendix D for the APW values of the one hundred Dewey divisions for Emporia State University based on 1980 circulation data and curricular offerings.)

Admittedly, there would be weaknesses in using any formula indiscriminately. However, the APW formula provides quantifiable rationale that would be useful in the often subjective process of making collection development decisions. The APW formula rests on the assumption that various types of use are identifiable and that use justifies collection development, with heavier use in certain areas justifying heavier acquisitions in those areas. Used widely and adapted to the curricular programs of an individual university, the APW formula can provide objective guidelines for the bulk of collection development decisions, decisions that must fit the most useful books requested into limited acquisitions budgets.

As a refinement of Pareto's Principle and Trueswell's $80 / 20$ rule, the circulation commonality and dispersion analyses showed that over 50 percent of a year's total library circulation is reflected in 20 percent of the Dewey divisional classifications, and 69 percent of a year's total library circulation is reflected in 34 percent of the Dewey divisional classifications. 
Appendix E presents a possible method of applying such findings to the budgetary considerations necessary in collection development. Using the total of the APW values computed from William Allen White Library circulation records at Emporia State University, one may ascertain a relative potential-use factor by dividing each APW value by the total of all APW values and multiplying the result by 100 . The resulting percentage demonstrates the relative use an acquisition in a given Dewey divisional classification might reasonably be expected to have.
If academic libraries carefully follow prioritized potential-use patterns in dispensing their book budgets-proportionately allotting the first half of available funds to those subject areas showing the first half of expected book use, allotting the first two-thirds of available funds to subject areas showing the first two-thirds of expected book use, and so forth-then sound collections can be developed in support of local-use patterns and demonstrated patron needs.

\section{REFERENCES AND NOTES}

1. The general obsolescence pattern consists of three elements: first, a high point of use sometime within the first four years after an item's acquisition; second, a decline in use over a period of years (roughly ten to fifteen years) until a low point of use is reached; and, third, a period of relatively steady, low use lasting, as found in this study, at least through an item's twenty-second year of shelf life.

2. "Dispersion," in this study, refers to the use of books that belong to a given academic department's curriculum-supporting collection by students not majoring in that department's curriculum. The term is distinct from "scatter," identified by Wilfred Ashworth ("The Information Explosion," Library Association Record, 76:63-68, April 1974) as the "order of decreasing productivity of papers relevant to a given topic" across a large number of periodicals that publish articles pertaining to a given discipline. As Samuel Bradford's law points out, journals principally devoted to the discipline carry, as a small group, more articles on a relevant topic than all the journals in the larger group of publications with a less-restricted focus. Thus, "dispersion" is a term for a type of user behavior while "scatter" is a term for a factor of diminishing productivity in relation to information gathering for a given topic.

3. Discussion and application of the "hard/soft" distinction are found in William E. McGrath's "Relationship Between Hard/Soft, Pure/Applied and Life/Nonlife Disciplines and Subject Book Use in a University Library," Information Processinf \& Management, 14:17-28, 1978, and in George V. Hodowanec's "Analysis of Variables Which Help to Predict Book and Periodical Use," Library Acquisitions: Practice and Theory, 4:75-85, 1980.

4. Charles F. Gosnell, "Obsolete Library Books," The Scientific Monthly, 64:421-27 (May 1947).

5. Charles F. Gosnell, "Systematic Weeding," College \& Research Libraries, 11:137-38 (Apr. 1950).

6. Gamet Hardin, "The Doctrine of Sufferance in the Library," College \& Research Libraries, 8:120-26 (Apr. 1967).

7. B. C. Brookes, "Obsolescence of Special Library Periodicals: Sampling Errors and Utility Contours," Journal of the American Society for Information Science, 21:320-29 (Sept.-Oct. 1970).

8. B. C. Brookes, "Numerical Methods of Bibliographical Analysis," Library Trends, 22:18-43 (July 1973).

9. Maurice B. Line and Alexander Sandison, "' 'Obsolescence' and Changes in the Use of Literature with Time," Journal of Documentation, 30:283-350 (1974).

10. Kenneth Hodges, "Chronological Order," Library Review, 25:57-62 (Summer 1975).

\section{APPENDIX A: SUGGESTED READING LIST}

Brookes, B. C. "Numerical Methods of Bibliographic Analysis," Library Trends 22:18-43 (July 1973). . "Obsolescence of Special Library Periodicals: Sampling Errors and Utility Contours," Jour-

nal of the American Society for Information Science 21:320-29 (Sept.-Oct. 1970). 
Burlington, William Stone. "The Obsolescence of Engineering Books." Masters thesis, Columbia Univ., 1951.

Gosnell, Charles F. "Obsolete Library Books," The Scientific Monthly 64:421-27 (May 1947). 1978). "Obsolescence of Books in College Libraries," Collection Management 2:167-82 (Summer . "Systematic Weeding," College \& Research Libraries 11:137-38 (Apr. 1950).

Hardin, Gamet. "The Doctrine of Sufferance in the Library," College \& Research Libraries 8:120-26 (Apr. 1967).

Hodges, Kenneth. "Chronological Order," Library Review 25:57-62 (Summer 1975).

Line, Maurice B., and Sandison, Alexander. " 'Obsolescence' and Changes in the Use of Literature with Time," Journal of Documentation 30:283-350 (1974).

Morse, Phillip, and Elston, Caroline. "A Probabilistic Model for Obsolescence," Operations Research 17:36-47 (1969).

Rouse, S. H., and Rouse, W. B. "Analysis of Monograph Obsolescence at Two Levels of an Interlibrary Loan Network," Information Processing and Management 15, no.5:219-25 (1979).

Seymore, Carol A. "Weeding the Collection: A Review of Research on Identifying Obsolete Stock; Monographs," Libri 22, no.2:137-48 (1972).

\section{APPENDIX B: SPEARMAN RANK ORDER CORRELATION}

A Spearman Rank Order Correlation (rho) test and a $t$-test were conducted to determine the constancy of circulation patterns at four academic libraries. The curriculum-supporting Dewey divisional classifications were grouped according to the primary instructional departments they serve and then ranked according to the percentage of total library circulation that they accounted for. Comparisons were made between subject area classifications at Emporia State University and three other schools: Bucknell, Colorado State University, and the University of Pittsburgh. After the comparisons were made, the subject-area classifications were grouped according to the departmental curriculumsupporting alignment at Emporia State. Then, based on individual subject-area circulation figures from the other schools, rankings were made according to each departmental group's percentage of total library circulation. The rank order correlations between circulations of subject-area classifications aligned by individual instructional departments at Emporia State and three other schools are illustrated below. The University of Pittsburgh's system of reporting circulation by subject areas made it necessary to use broader bases of comparison between Emporia State and Pittsburgh than the departmental bases otherwise compared.

\section{SPEARMAN RANK ORDER CORRELATION and T-TEST:}

Emporia State University and Bucknell University

Emporia State University and Colorado State University

Emporia State University and University of Pittsburgh

$$
\begin{gathered}
\text { rho }=0.645 ; t=3.158 \\
\quad(\text { significant at } P \leqslant .01) \\
\text { rho }=0.688 ; t=3.457 \\
(\text { significant at } P \leqslant .01) \\
\text { rho }=0.845 ; t=4.74 \\
(\text { significant at } P \leqslant .01)
\end{gathered}
$$

Therefore, all correlations show a probability of significant rank order correspondence at levels of 99 percent or more. 


\section{APPENDIX C: DEWEY TO LC CONVERSION CHART}

\begin{tabular}{|c|c|c|c|}
\hline DEPAKTMENT & DDC & SUBECT AREAS & $L C$ \\
\hline Art & $\begin{array}{l}700 \\
730 \\
740 \\
750 \\
760\end{array}$ & $\begin{array}{l}\text { The Arts } \\
\text { Fine \& decorative } \\
\text { Plastic arts, sculpture } \\
\text { Drawing } \\
\text { Painting \& paintings } \\
\text { Graphic arts } \\
\text { Printaaking \& prints }\end{array}$ & $\begin{array}{l}\mathrm{CJ} \\
\mathrm{N} \\
\mathrm{NB} \\
\mathrm{NC} \\
\mathrm{ND} \\
\mathrm{NE} \\
\mathrm{NK} \\
\mathrm{NX} \\
\mathrm{TT} 1-\mathrm{TT160} \\
\mathrm{TT} 697-\mathrm{TT} 924 \\
\end{array}$ \\
\hline Biology & $\begin{array}{l}570 \\
580 \\
590 \\
\end{array}$ & $\begin{array}{l}\text { Life Sciences } \\
\text { Physical Anthropology } \\
\text { B1ology } \\
\text { Physiology } \\
\text { Microbiology } \\
\text { Botanical Sciences } \\
\text { Zoological Sciences } \\
\text { Medical Sciences }\end{array}$ & $\begin{array}{l}\text { QN49-CN296 } \\
\text { QH301-QH671 } \\
\text { QR } \\
Q \mathrm{QL} \\
\text { QP } \\
\text { QR } \\
\text { R } \\
\text { RB-RG } \\
\text { RJ-RM } \\
\text { RS-RT } \\
\text { RV } \\
\text { RX } \\
\text { RZ }\end{array}$ \\
\hline Business & $\begin{array}{l}330 \\
340 \\
650\end{array}$ & $\begin{array}{l}\text { Econonics } \\
\text { Labor } \\
\text { Financial } \\
\text { Land } \\
\text { Cooperatives } \\
\text { Public finance } \\
\text { International economics } \\
\text { Production } \\
\text { Macroeconoales } \\
\text { Law } \\
\text { Managenent }\end{array}$ & 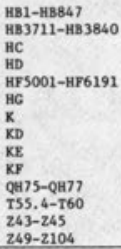 \\
\hline
\end{tabular}

- This subject area(s) supported no curricular progras in

\begin{tabular}{|c|c|c|c|}
\hline DEPAKTMENT & DDC & SUBDECT AREAS & LC \\
\hline \multirow[t]{2}{*}{$\begin{array}{l}\text { Home } \\
\text { Econonics }\end{array}$} & 390 & $\begin{array}{l}\text { Customs, Et1quette, } \\
\text { Folklore }\end{array}$ & \\
\hline & 640 & Hone Economics & $\begin{array}{l}\text { GT } \\
\text { Tr950-TT999 } \\
\text { TX }\end{array}$ \\
\hline \multirow[t]{9}{*}{$\begin{array}{r}\text { Industrial } \\
\text { Education }\end{array}$} & 600 & $\begin{array}{l}\text { Technology } \\
\text { Buildings }\end{array}$ & $\mathrm{Na}$ \\
\hline & 670 & $\begin{array}{l}\text { Manufactures } \\
\text { Clvic o landscape art }\end{array}$ & T1-TS3 \\
\hline & $\begin{array}{l}680 \\
690\end{array}$ & Architecture & T201-T995 \\
\hline & 690 & & nis \\
\hline & 720 & & TS195-TS1982 \\
\hline & & & TS2220-TS2283 \\
\hline & & & TT161-TT267 \\
\hline & & & TT387-TT695 \\
\hline & & & $2116-2276$ \\
\hline \multirow{11}{*}{$\begin{array}{l}\text { Library } \\
\text { Sefence }\end{array}$} & 000 & \multirow{11}{*}{$\begin{array}{l}\text { Generalities } \\
\text { Library \& Information } \\
\text { Science }\end{array}$} & $A E$ \\
\hline & 010 & & AC \\
\hline & 020 & & AI \\
\hline & 030 & & M \\
\hline & 040 & & AN \\
\hline & $\begin{array}{l}050 \\
060\end{array}$ & & \\
\hline & 070 & & \\
\hline & 080 & & \\
\hline & 090 & & $\begin{array}{l}\text { CD921-CD4279 } \\
\text { PN4699-PN5650 }\end{array}$ \\
\hline & & & Q300-Q385 \\
\hline & & & $21-239$ \\
\hline & & & \\
\hline $\begin{array}{l}\text { Mathe- } \\
\text { matics }\end{array}$ & 510 & Mathemat ics & $Q A$ \\
\hline \multirow[t]{2}{*}{ Music } & 780 & Music & M \\
\hline & & & $\mathrm{ma}$ \\
\hline & & & $\mathrm{MT}$ \\
\hline
\end{tabular}

\begin{tabular}{|c|c|c|c|}
\hline DEPARTMERT & DDC & SUBJECT AREAS & $L C$ \\
\hline Education & 370 & Education & $\begin{array}{l}\mathrm{L}-\mathrm{LH} \\
\mathrm{LJ} \\
\mathrm{LT}\end{array}$ \\
\hline Eng11sh & $\begin{array}{l}400 \\
410 \\
420 \\
800 \\
810 \\
820\end{array}$ & $\begin{array}{l}\text { Language } \\
\text { Linguistics } \\
\text { Literature }\end{array}$ & $\begin{array}{l}\text { CN } \\
\text { P1-P86 } \\
\text { P101-P900 } \\
\text { PE } \\
\text { PN1-PN1551 } \\
\text { PN1600-PN1999 } \\
\text { PN3311-PN6500 } \\
\text { PN6011-PN6790 } \\
\text { PR } \\
\text { PS } \\
\text { 2105-2115 } \\
\text { P2 } \\
\end{array}$ \\
\hline $\begin{array}{l}\text { Fore1gn } \\
\text { Languages }\end{array}$ & $\begin{array}{l}430 \\
440 \\
450 \\
460 \\
470 \\
480 \\
490 \\
830 \\
840 \\
850 \\
860 \\
870 \\
880 \\
890\end{array}$ & $\begin{array}{l}\text { Fore1gn languages } \\
\text { and 11terature }\end{array}$ & $\begin{array}{l}\text { P901-P1081 } \\
\text { PA } \\
\text { PB } \\
\text { PC } \\
\text { PD } \\
\text { PF } \\
\text { PC } \\
\text { PH } \\
\text { PJ-PM } \\
\text { PQ } \\
\text { PT }\end{array}$ \\
\hline $\begin{array}{l}\text { Health } 6 \\
\text { Physical } \\
\text { Education }\end{array}$ & $\begin{array}{l}610^{\circ} \\
790\end{array}$ & $\begin{array}{l}\text { Medical Sciences } \\
\text { Recreation }\end{array}$ & $\begin{array}{l}\text { GV } \\
\text { OM } \\
R A 421-R A 9 S 4 \\
R A 1001-R A 1270\end{array}$ \\
\hline
\end{tabular}

* Books related to physical education programs only.

\begin{tabular}{|c|c|c|c|}
\hline DEPARTENT & DDC & SUBUECT AREAS & LC \\
\hline $\begin{array}{l}\text { Physical } \\
\text { Selence }\end{array}$ & $\begin{array}{l}500 \\
520 \\
530 \\
540 \\
550 \\
560 \\
620 * \\
630 * \\
660 * \\
770 *\end{array}$ & $\begin{array}{l}\text { Pure Sc1ences } \\
\text { Natural H1story } \\
\text { Microscopy } \\
\text { Astronomy } \\
\text { Physics } \\
\text { Chea1stry } \\
\text { Geology } \\
\text { Meteorology } \\
\text { General Hydrology } \\
\text { Paleontology } \\
\text { Paleozoology }\end{array}$ & $\begin{array}{l}\mathrm{CE} \\
\mathrm{GA} \\
\mathrm{CB} 400-\mathrm{CB} 2998 \\
\mathrm{CC} \\
\mathrm{Q1-Q299} \\
\mathrm{QA} \\
\mathrm{QB}-\mathrm{QE} \\
\mathrm{QH1}-\mathrm{QH} 74 \\
\mathrm{QH201}-\mathrm{QH} 278 \\
\mathrm{TA} \\
\mathrm{TC} \\
\mathrm{TF}-\mathrm{TC} \\
\mathrm{TJ}-\mathrm{TL} \\
\mathrm{TN} \\
\mathrm{S}-\mathrm{SK} \\
\mathrm{TS} 212 \mathrm{O}-\mathrm{TS} 2159 \\
\mathrm{TT} 300-\mathrm{TT} 385 \\
\mathrm{TP} \\
\mathrm{TR}\end{array}$ \\
\hline Paychology & $\begin{array}{l}130 \\
150\end{array}$ & Psychology & By \\
\hline $\begin{array}{l}\text { Social } \\
\text { Studies/ } \\
\text { Anthro- } \\
\text { pology }\end{array}$ & $\begin{array}{l}100 \\
110 \\
120 \\
140 \\
160 \\
170 \\
180 \\
190 \\
200- \\
290 \\
300- \\
320\end{array}$ & $\begin{array}{l}\text { Philosophy and related } \\
\text { disciplines } \\
\text { Metaphysics } \\
\text { Cosmology } \\
\text { Aesthetics } \\
\text { Ethics } \\
\text { Logic } \\
\text { Religion } \\
\text { Social Seiences } \\
\text { Population, Demography }\end{array}$ & $\begin{array}{l}\text { BL-BX } \\
\text { H-HA } \\
\text { HB848- } 18 B 3700\end{array}$ \\
\hline
\end{tabular}

- Th1s subject area(s) supported no curricular progras in this study. 


\section{APPENDIX C, CONTINUED}

\begin{tabular}{|c|c|c|c|}
\hline DEPARTMENT & DDC & SUBUECT AREAS & $L C$ \\
\hline $\begin{array}{l}\text { Social } \\
\text { Studies/ } \\
\text { Anthro- } \\
\text { pology }\end{array}$ & $\begin{array}{l}350 \\
360 \\
380 \\
900- \\
990\end{array}$ & $\begin{array}{l}\text { Political Science } \\
\text { Public Adainistration } \\
\text { Military art \& science } \\
\text { Social problem services } \\
\text { association } \\
\text { Comerce, Conmunications, } \\
\text { Transportation } \\
\text { History of Ceography }\end{array}$ & 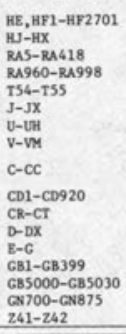 \\
\hline Speech & $\begin{array}{l}\text { Portion } \\
\text { of } 000 \\
\text { Portion } \\
\text { of } 790\end{array}$ & $\begin{array}{l}\text { Communcation } \\
\text { Performing Arts }\end{array}$ & $\begin{array}{l}\text { P87-P96 } \\
\text { PN1560-PN1590 } \\
\text { PN2000-PN3299 }\end{array}$ \\
\hline
\end{tabular}

\section{APPENDIX D: ACQUISITION PRIORITY WEIGHTING (APW)}

This appendix provides APW (acquisition priority weighting) values for the one hundred Dewey second-level divisions based on the analyses of book circulation and curriculum offerings at Emporia State University in calendar-year 1980 . These values can be used for relative comparisons to support subjective judgments in collection development decisions. Even though a Spearman Rank Order Correlation (rho) test shows significant statistical correlation between the rank ordering of Dewey divisional circulation at Emporia State and at three other universities, other academic libraries interested in using this formula may want to develop an immediacy/intensity table, a dispersion table, and a circulation commonality table based on the specific curricular structure and emphasis of their own universities. Individual academic library rankings of immediacy and intensity of use, dispersion of use, and commonality of use would not help verify the findings of the Emporia State University analysis but also would provide individual academic libraries with directly applicable data tailored to particular universities.

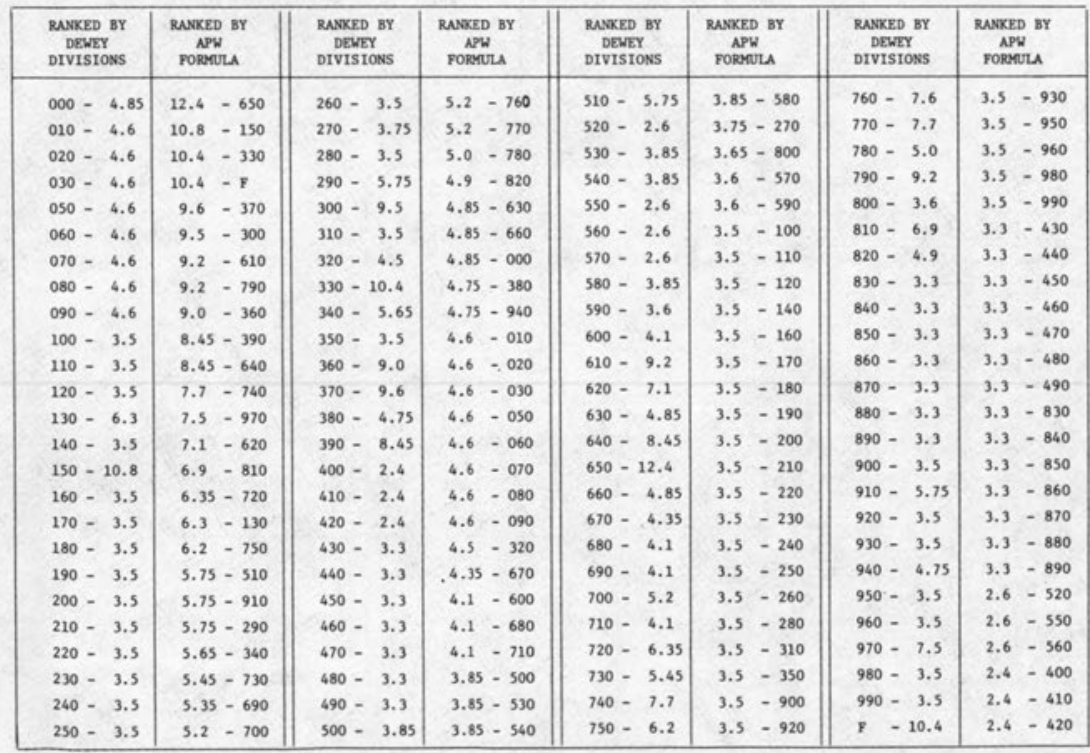


APPENDIX E: POTENTIAL USE OF PERCENTAGES (APW VALUES TOTAL OF $475.35100 \%$ )

$\begin{array}{llllllll}650 & 2.61 & 760 & 1.09 & 580 & .81 & 930 & .74 \\ 150 & 2.27 & 770 & 1.09 & 270 & .79 & 950 & .74 \\ 330 & 2.19 & 780 & 1.05 & 800 & .77 & 960 & .74 \\ \text { F } & 2.19 & 820 & 1.03 & 570 & .76 & 980 & .74 \\ 370 & 2.02 & 630 & 1.02 & 590 & .76 & 990 & .74 \\ 300 & 2.00 & 660 & 1.02 & 100 & .74 & 430 & .69 \\ 610 & 1.94 & 000 & 1.02 & 110 & .74 & 440 & .69 \\ 790 & 1.94 & 380 & 1.00 & 120 & .74 & 450 & .69 \\ 360 & 1.89 & 940 & 1.00 & 140 & .74 & 460 & .69 \\ 390 & 1.78 & 010 & .97 & 160 & .74 & 470 & .69 \\ 640 & 1.78 & 020 & .97 & 170 & .74 & 480 & .69 \\ 740 & 1.62 & 030 & .97 & 180 & .74 & 490 & .69 \\ 970 & 1.58 & 050 & .97 & 190 & .74 & 830 & .69 \\ 620 & 1.49 & 060 & .97 & 200 & .74 & 840 & .69 \\ 810 & 1.45 & 070 & .97 & 210 & .74 & 850 & .69 \\ 720 & 1.34 & 080 & .97 & 220 & .74 & 860 & .69 \\ 130 & 1.33 & 090 & .97 & 230 & .74 & 870 & .69 \\ 750 & 1.30 & 320 & .95 & 240 & .74 & 880 & .69 \\ 510 & 1.21 & 670 & .92 & 250 & .74 & 890 & .69 \\ 910 & 1.21 & 600 & .86 & 260 & .74 & 520 & .55 \\ 290 & 1.21 & 680 & .86 & 280 & .74 & 550 & .55 \\ 340 & 1.19 & 710 & .86 & 310 & .74 & 560 & .55 \\ 730 & 1.15 & 500 & .81 & 350 & .74 & 400 & .50 \\ 690 & 1.13 & 530 & .81 & 900 & .74 & 410 & .50 \\ 700 & 1.09 & 540 & .81 & 920 & .74 & 420 & .50\end{array}$

